\title{
Co-pyrolysis of rubberwood sawdust (RWS) and polypropylene (PP) in a fixed bed pyrolyzer
}

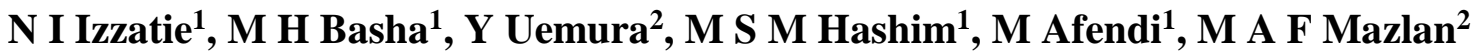 \\ ${ }^{1}$ Mechanical Engineering Programme, School of Mechatronic Engineering, Universiti \\ Malaysia Perlis, Pauh Putra Campus, 02600 Arau, Perlis, Malaysia. \\ Phone: +6049885166; Fax: +6049885167 \\ "E-mail: hafifbasha@unimap.edu.my \\ ${ }^{2}$ Centre for Biofuel and Biochemical Research, Institute of Self Sustainable Building, \\ Universiti Teknologi PETRONAS, Malaysia.
}

\begin{abstract}
Co-pyrolysis of rubberwood sawdust (RWS) waste and polypropylene (PP) was carried out at different temperatures $\left(450,500,550\right.$, and $\left.600^{\circ} \mathrm{C}\right)$ with biomass to plastics ratio $1: 1$ by using fixed bed drop-type pyrolyzer. The yield of pyrolysis oil has an increasing trend as the temperature increased from $450^{\circ} \mathrm{C}$ to $550^{\circ} \mathrm{C}$. However, the pyrolysis oil yield dropped at a temperature of $600^{\circ} \mathrm{C}$. Co-pyrolysis of RWS and PP generated maximum pyrolysis oil with $36.47 \mathrm{wt} . \%$ at $550^{\circ} \mathrm{C}$. The result is compared with the pyrolysis of RWS only without plastics, with the same feedstock, and the maximum pyrolysis oil yield obtained was $33.3 \mathrm{wt} . \%$. The water content in pyrolysis oil of co-pyrolysis RWS with PP is lower than RWS only with 54.2 wt.\% and 62 wt.\% respectively. Hydrocarbons, acyclic olefin, alkyl, and aromatic groups are the major compound in the pyrolysis oil from the co-pyrolysis process. Carbon monoxide (52.2 vol.\%) and carbon dioxide (38.2 vol.\%) are the major gas components.
\end{abstract}

Keywords: Co-pyrolysis; Rubberwood sawdust residue; Polypropylene; fixed-bed drop type pyrolyzer

\section{INTRODUCTION}

As the world is reaching peak oil usage, the depletion of fossil fuel is imminent. Alternative energy source should be sought to prepare us for the uncharted future where fossil fuel is scarce. Biomass is considered a carbon-neutral energy source that is not hazardous to the environment since it does not increase $\mathrm{CO}_{2}$ concentration in the atmosphere during the energy conversion process. It also has high volatile matter content and low contents of nitrogen, sulphur, and ash that can contribute pollution to the environment when burned [1].

Biomass can be cultivated exclusively for energy production such as corn and sugarcane, however, the problem arises from the usage of land that can be otherwise be used to grow food, thus creating the debate of food vs fuel [2]. To avoid this problem, the biomass source from agricultural residue is preferred. Cash crop such as oil palm and rubber tree is widely cultivated for the production of palm oil and latex, and this industry will produce a significant amount of waste as a potential biomass source for energy production [3-4]. 
Rubber tree has been widely cultivated in ASEAN countries such as Thailand, Indonesia, Vietnam, and Malaysia, with the amount of natural rubber production are 4 million tonnes, 1 million tonnes and 600 thousand tonnes respectively [5]. After 25 years of the latex yielding, the rubber trees are cut down and the wood could be utilized for many downstream processed such as sawmilling, furniture, panel products, builders carpentry and joinery. In Malaysia alone, the production of rubberwood biomass waste is recorded at 1.5 $\mathrm{x} 10^{6} \mathrm{~m}^{3}$ in volumes, with an estimation energy content of 76 million GJ [3].

Pyrolysis is one of the potential processes to elevate rubberwood residue as valuable added fuels. Pyrolysis process is defined as the direct thermal decomposition of the organic materials in the absence of oxygen. Pyrolysis of rubber wood residue waste was studied by Mazlan et al [6]. They found out as the temperature increased the yield of pyrolysis oil and NCG increased. Maximum pyrolysis oil at $33.0 \mathrm{wt} \%$ was generated at temperature $550^{\circ} \mathrm{C}$ and when the temperature increased, continues volatilization reaction takes place caused the yield of biochar decreased. However, in general, pyrolysis oil has poor properties, such as low calorific value, high oxygen content [7], high water content, corrosiveness and instability [8], [9], which resist its direct application as a transportation fuel and thus, need upgrading before application. Co-pyrolysis process has been suggested by researchers because of its potential in producing high-grade pyrolysis oil [10]-[12].

The presence of plastics as co-feeds act as good hydrogen source during pyrolysis which leads to a decrease in oxygen content in pyrolysis oil. As plastics have significantly lower water content than biomass and do not absorb moisture [13], a costly drying process is not needed. Aside from upgrading the pyrolysis oil, adding plastics can also solve the problem of plastic wastes manage. Plastic waste management has been a problem, as domestic plastic usage is on the rise. In 2015, $6300 \mathrm{Mt}$ of plastic has been produced, and plastics waste in landfill is expected to reach $12,000 \mathrm{Mt}$ on 2050 if this trend continues[14]. Polyethylene and polypropylene are the two of the most produced types of non-fiber plastics, with the share as large as $36 \%$ and $21 \%$ respectively [14]. Exploring the use of rubberwood residue mixed with plastics is therefore beneficial as both feedstocks are abundantly available. However, no specific research has been done for this combination of feedstocks.

In this work, rubberwood residue was co-pyrolyzed with polypropylene (PP) at ratio 1:1 using a fixed-bed drop type pyrolyzer. To identify the upgrading effect of the presence of PP in the blend of feedstock, the solid, liquid and gas production is compared with the pyrolysis of RWS only.

\section{EXPERIMENTAL SET UP}

\section{Feedstock}

The biomass used in this work is the rubberwood residue (RWS) which is collected from a sawmill in Perak, Malaysia. The raw material was in the form of small particles and sieved to a size range of $0.15-0.50 \mathrm{~mm}$ as it favors higher pyrolysis reaction [15]. Prior to the experiment, the RWS was dried in a drying oven for $24 \mathrm{~h}$ at $105^{\circ} \mathrm{C}$ to diminish moisture. Polypropylene (PP) was collected from a food container waste and was cut into sizes of 0.3 $\mathrm{mm} \times 0.3 \mathrm{~mm}$. The characteristics of the feedstocks are shown in Table 1. 
Table 1. Characteristics of feedstocks

\begin{tabular}{lll}
\hline Characteristics & RWS & PP \\
\hline Proximate analysis (wt. \%) & & \\
Moisture & 4.3 & - \\
Ash & 1.8 & - \\
Volatile content & 79.8 & 99.2 \\
Fixed carbon & 14.1 & 0.8 \\
\hline Elemental analysis (wt. \%) & & \\
\hline $\mathrm{C}$ & 44.2 & 87.8 \\
$\mathrm{H}$ & 7.2 & 10.6 \\
$\mathrm{~N}$ & 0.3 & 0.2 \\
$\mathrm{O}$ & 48.3 & 1.4 \\
\hline Calorific value (kJ/g) & 18.9 & 46.3 \\
Hemicellulose (wt.\%, Dry) [16] & 34.60 & - \\
Cellulose (wt.\%, Dry) [16] & 18.30 & - \\
Lignin (wt.\%, Dry) & 25.50 & - \\
[16] & & \\
\hline
\end{tabular}

\section{Experimental setup}

Experiments were carried out using fixed-bed, drop type pyrolyzer as shown in Figure 1. The reactor was connected to nitrogen gas lines and vacuum to create an inert condition. Inert conditions were achieved by purging nitrogen three times, to ensure the total removal of oxygen or air in the system. The pyrolyzer was designed with two ball valves at the biomass holder zone. The drop-type pyrolyzer is made of a stainless steel cylindrical reactor with a size of $155 \mathrm{~mm}$ height and $53 \mathrm{~mm}$ internal diameter. The reactor was placed inside the electrical heater and was insulated to minimize heat loss during the experiment. A K-type thermocouple was embedded inside the reactor to measure the pyrolysis temperature.

Two condensers were connected to the reactor to collect the liquid product. Both condensers were immersed in the cool water bath. The sampling gas bag was connected to the outlet of the vapour trap to accumulate the non-condensable gases (NCG). 


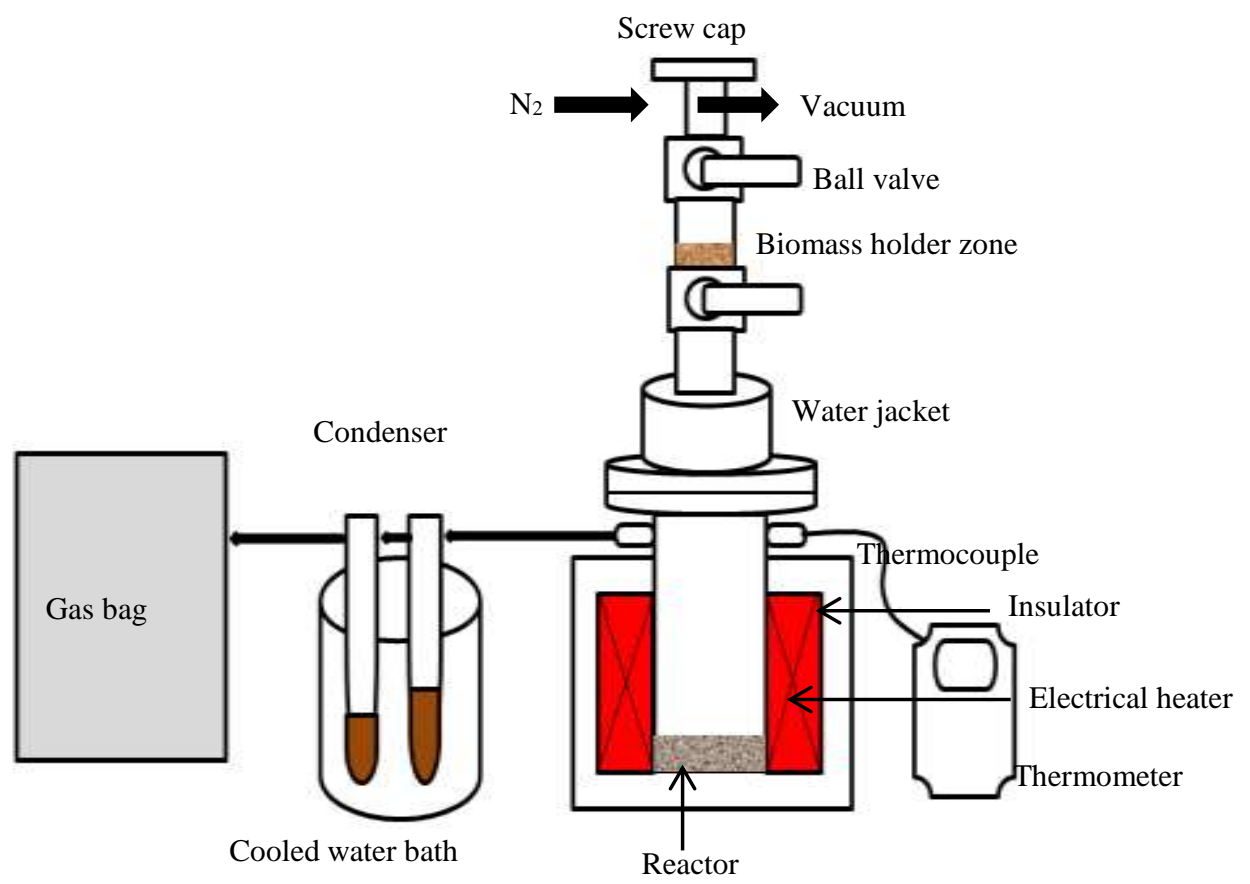

Figure 1. Fixed-bed drop type pyrolyzer schematic diagram

\section{Experimental procedure}

The co-pyrolysis experiment was accomplished with 1:1 RWS to PP mass ratio at different temperatures. Each experiment was conducted three times to ensure consistency. After the reactor was set in an inert condition by purging Nitrogen gas, the reactor was heated to the desired temperature, and then the feedstocks were dropped down by gravity by opening the ball valve. The experiment was performed using $15 \mathrm{~g}$ of feedstocks at the yield of pyrolysis oil, biochar, and NCG products were collected. The duration of the experiment was held for approximately 15 minutes until no production of gas fumes was observed. The flowchart for the summary of experimental procedure is shown in Figure 2.

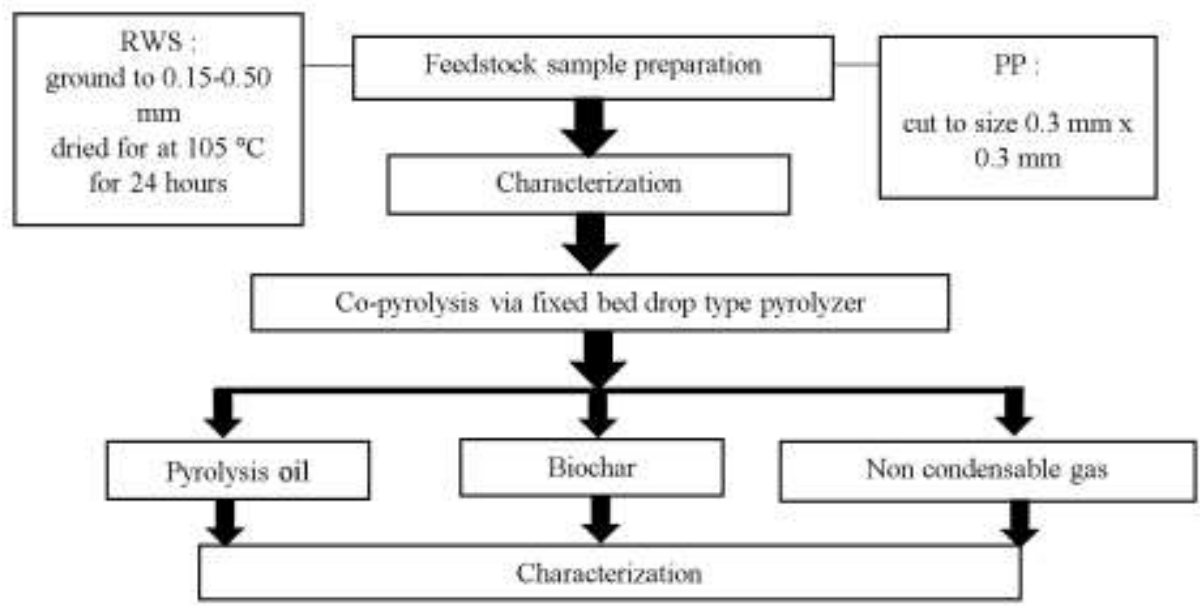

Figure 2. Experimental procedure flow chart 


\section{Characterization of feedstocks and co-pyrolysis products}

To study the effect of feedstock on the quantities of the quantities of co-pyrolysis product, the analysis of oil products from the maximum pyrolysis temperature was executed. The water content of pyrolysis oil was evaluated by a volumetric Karl Fisher titrator (Mettler Toledo, V30). The elemental analysis was accomplished using a Perkin Elmer $2400 \mathrm{CHN}$ Analyzer. The value of Hemi-cellulose, cellulose and lignin of RWS is referred to published literature [16]. The calorific value was computed by an IKA WERKE (2000) bomb calorimeter to calculate the energy contained in pyrolysis oil and biochar. Gas Chromatograph/ Thermal Conductivity Detector (GC-TCD) (Shimadzu GC-8A) was used to define the composition of non-condensable gases, with a Davison Grade 12 Silica Gel packed column to detect $\mathrm{CO}, \mathrm{CH}_{4}, \mathrm{O}_{2}$, and $\mathrm{H}_{2}$. The organic compound of the pyrolysis oil was detected by using a Gas Chromatograph Mass Spectrometry (GC-MS). The GC-MS analysis was carried out with an Agilent Technology model 7890A series. A BPX-5 capillary column was selected with $0.25 \mathrm{~mm}, 30 \mathrm{~mm}$ and $0.25 \mu \mathrm{m}$ of its internal diameter, length and film thickness correspondingly. Thermogravimetric analysis (TGA) was done on the RWS and PP feedstock respectively using the TA Instruments model QA50 with $60 \mathrm{~mL} / \mathrm{min}$ of $\mathrm{N}_{2}$ flowrate at a heating rate of $10{ }^{\circ} \mathrm{C} / \mathrm{min}$. Figure 3 and figure 4 shows the thermogravimetric curves for the RWS and PP plastic respectively. Around $220^{\circ} \mathrm{C}$, the RWS started to break down, whereas PP starts to decompose approximately at $400^{\circ} \mathrm{C}$ as seen in Figure 2 and Figure 3 respectively.

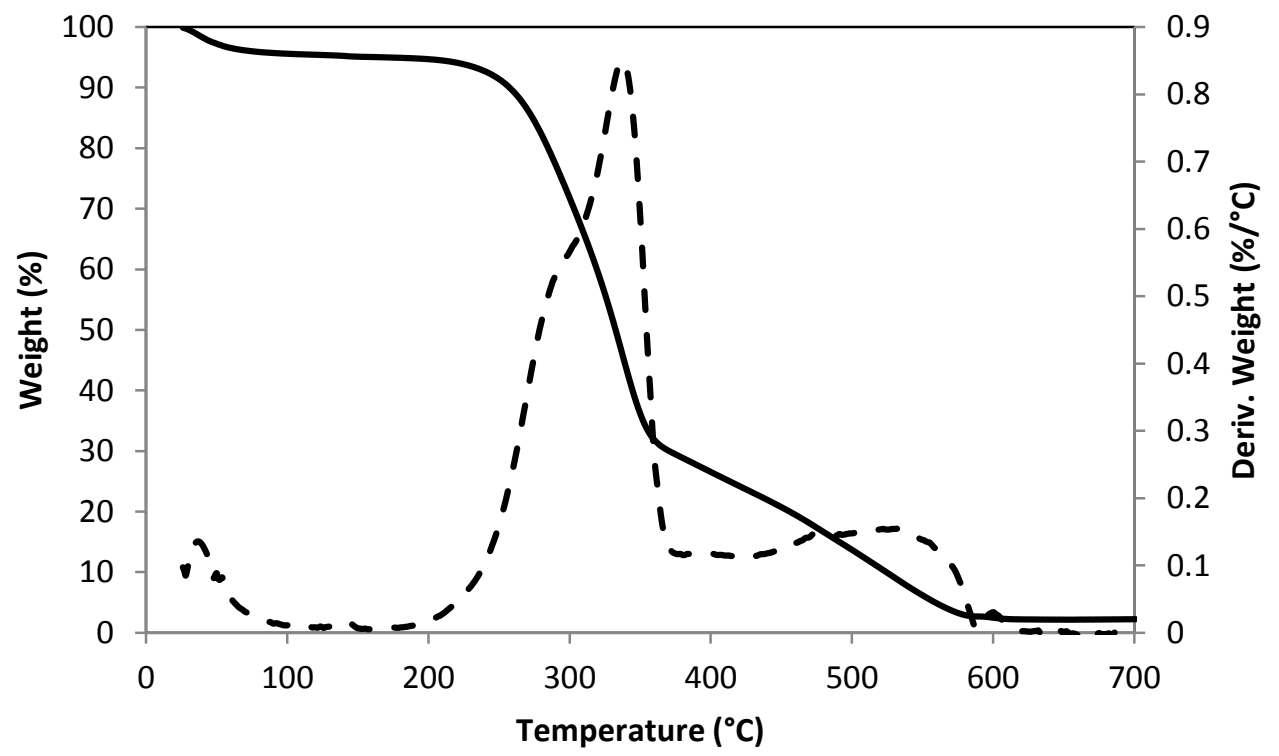

Figure 3. TGA of RWS feedstock 


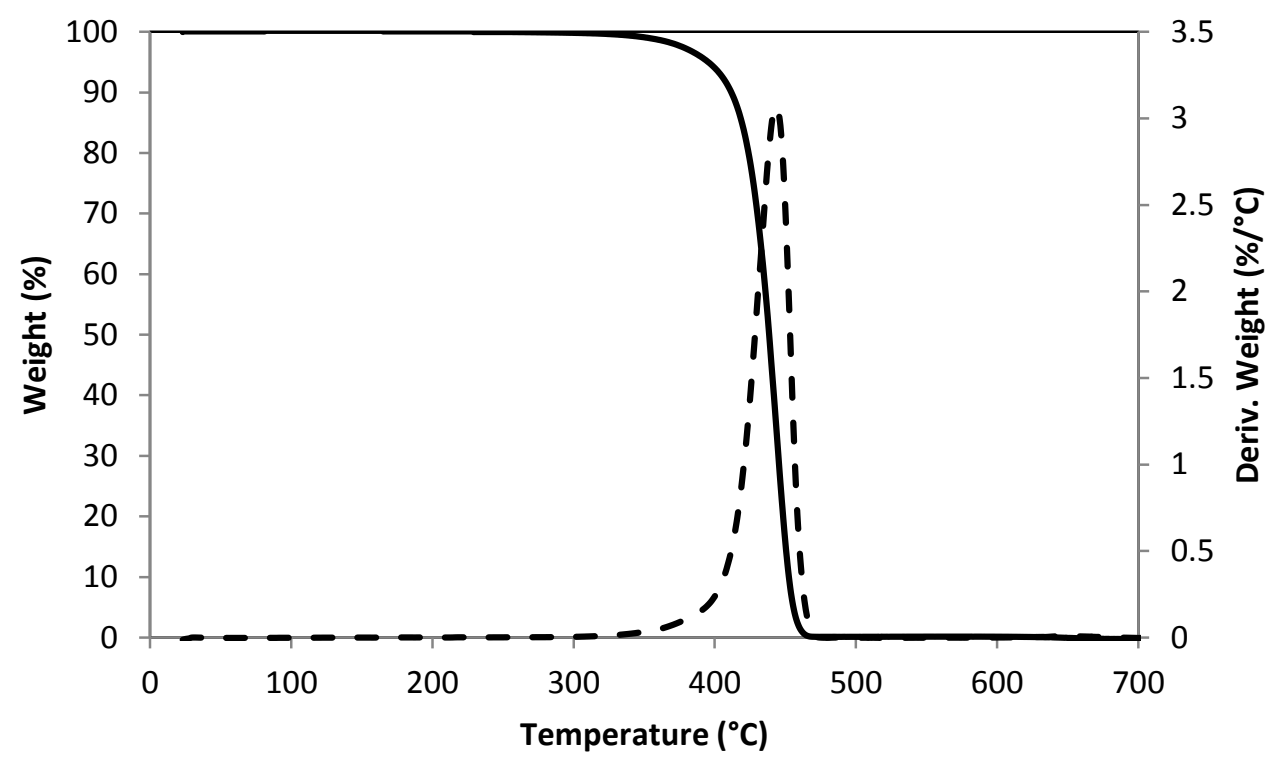

Figure 4. TGA of PP feedstock

\section{RESULTS AND DISCUSSION}

\section{Effect of temperature on co-pyrolysis products}

To study the effect of temperature on the co-pyrolysis products, the experiment was held at $450{ }^{\circ} \mathrm{C}, 500{ }^{\circ} \mathrm{C}, 550{ }^{\circ} \mathrm{C}$, and $600{ }^{\circ} \mathrm{C}$. These temperatures were selected as from the TGA results, the pyrolysis of RWS and PP starts at $220{ }^{\circ} \mathrm{C}$ and $400{ }^{\circ} \mathrm{C}$ respectively. In order for both of the feedstock to decompose, temperature above $400{ }^{\circ} \mathrm{C}$ was used. The yield of resulting products from co-pyrolysis of RWS and PP were discussed for examining the effect of pyrolysis temperature on 1:1 feedstock ratio. The co-pyrolytic yield from RWS and PP produced pyrolysis oil, biochar, and non-condensable gases.

As shown in Figure 5, the yield of pyrolysis oil has an inclined trend as the temperature increased from $450^{\circ} \mathrm{C}$ to $550^{\circ} \mathrm{C}$. This can be explained as the higher temperature will cause greater primary decomposition of the feedstock and secondary decomposition of char. This also explained the decrease of char with increasing temperature. Maximum pyrolysis oil yield is achieved at $550^{\circ} \mathrm{C}$ with $36.47 \mathrm{wt} \%$. However, the pyrolysis oil yield abruptly dropped at a temperature of $600^{\circ} \mathrm{C}$, together with a further decrease of char, producing more non-condensable gas. The very high temperature will promote further cracking of condensable vapour to non-condensable gas [17], explaining the decrease of pyrolysis oil yield. 


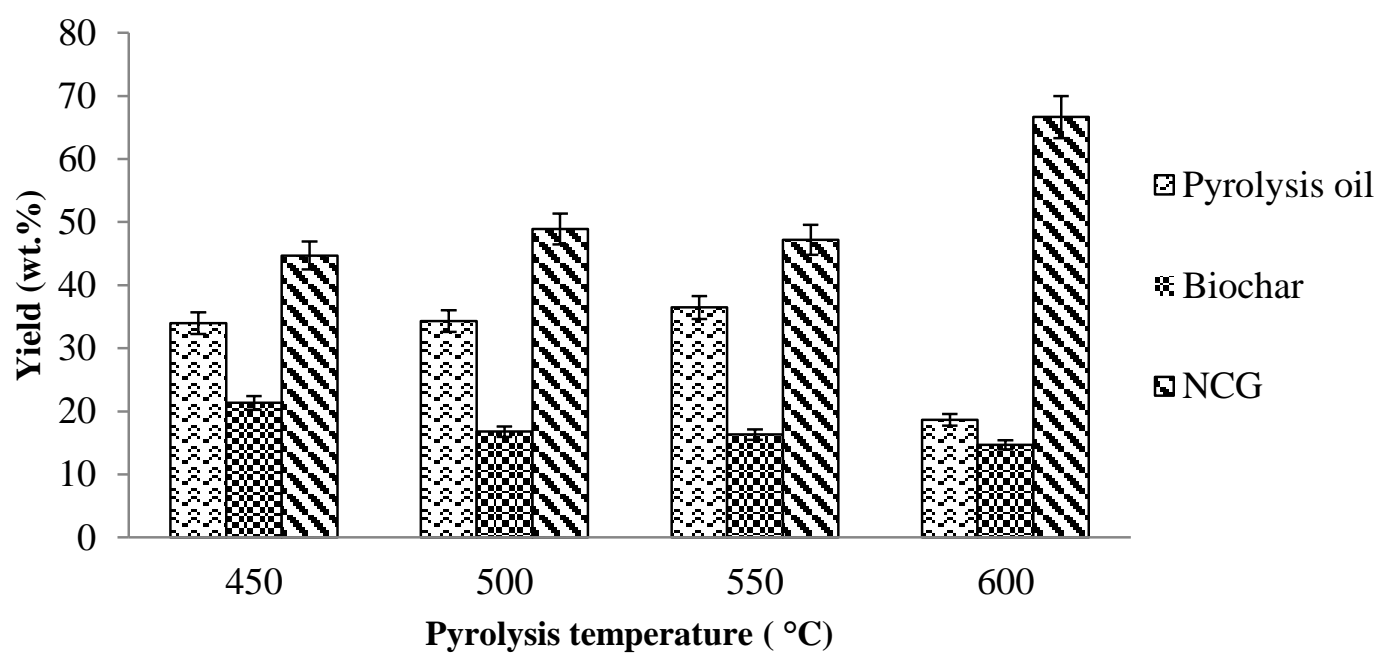

Figure 5. Product yield for the co-pyrolysis of RWS with PP

However, the comparison between pyrolysis of RWS alone was done with the same weight to compare the product yields with co-pyrolysis product yields. Pyrolysis of RWS only in Figure 6 shows the pyrolysis oil is lower compared to co-pyrolysis process. The Maximum pyrolysis oil of pyrolysis RWS only at temperature $550^{\circ} \mathrm{C}$ with $33.3 \mathrm{wt}$ \% compared to copyrolysis with PP at $36.47 \mathrm{wt} \%$. As PP contains more volatile matter, adding PP to the feedstock will yield more liquid and gaseous product with less char yield.

The same trend was observed for the effect of temperature on the pyrolysis of RWS only and co-pyrolysis oil RWS with PP. As the temperature increased, the pyrolysis oil and NCG increased while biochar decreased, until a certain point in which when higher temperature is used, the pyrolysis oil yield will decrease.

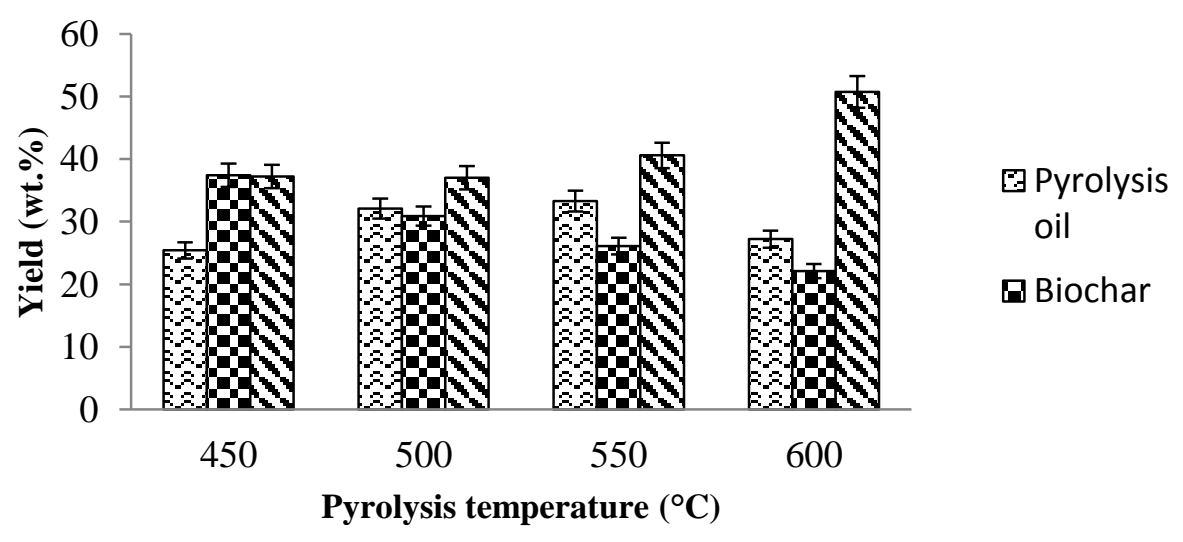

Figure 6. Product yield for pyrolysis of RWS only

\section{Characteristics of products}

The pyrolysis oil collected from pyrolysis process were red-brown coloured and had an acrid odour. Table 2 summarized the characteristics and properties of pyrolysis RWS only and copyrolysis of RWS with PP products. 
Product yields from the maximum pyrolysis temperature at $550^{\circ} \mathrm{C}$ for the pyrolysis of RWS only and RWS and PP were used to products analysis.

Table 2. Characteristics and properties analysis of products yields

\begin{tabular}{lllll}
\hline Characteristics & RWS only & \multicolumn{3}{c}{$\begin{array}{l}\text { Co-pyrolysis } \\
\text { with PP }\end{array}$} \\
\cline { 2 - 5 } & Pyrolysis oil & Bio-char & $\begin{array}{l}\text { Pyrolysis } \\
\text { oil }\end{array}$ & Bio-char \\
& & & & 2.6 \\
\hline Proximate analysis (wt.\%) & & 2.7 & - & 5.2 \\
Moisture & - & 4.6 & - & 54.1 \\
Ash & - & 51.2 & - & 38.1 \\
Volatile & - & 41.5 & & \\
Fixed carbon & & & 43.1 & 78.2 \\
\hline Elemental analysis (wt.\%) & 19.7 & 74.5 & 13.9 & 1.5 \\
& 10.2 & 2.5 & 0.1 & 0.5 \\
\hline C & 0.1 & 0.4 & 42.9 & 19.8 \\
H & 70.0 & 22.6 & 54.3 & - \\
N & 62.0 & - & 14.8 & 29.4 \\
O & 7.2 & 27.6 & & \\
\hline Water content (wt.\%) & & & & \\
Calorific value (kJ/g) & & & & \\
\hline & & & & \\
\end{tabular}

It can be observed that the water content in pyrolysis oil of co-pyrolysis RWS with PP is lower than RWS only with $54.2 \mathrm{wt} . \%$ and $62 \mathrm{wt} . \%$ respectively. The presence of PP in the co-pyrolysis process with RWS can balance the $\mathrm{C}, \mathrm{H}$, and $\mathrm{O}$ in the feedstock, with cogent effect on the properties of degradation products [18]. To control the water content of pyrolysis oil, some researcher concluded that drying the feedstock (approaching zero) show to decrease water content [19]. High water content in pyrolysis oil is an unsuitable component because it can be destructive for the ignition performance. High water content also affects the calorific value of the pyrolysis oil and might reduce it potentially as energy [20].

In addition, hydrogen is one of the important components with a point to increase the calorific value because it has the highest heating value [21]. Rubberwood is categorized as a hardwood which has higher lignin content and might have relatively higher biochar yields [22]. The biochar yields of co-pyrolysis have high carbon content and low oxygen content, thus biochar may be used as carbon fibers, soil fertilizer, chemicals, activated carbon, etc. [20], [23].

Variation in organic yields is due to differences in the physical and chemical composition of feedstock. The liquid fractions were composed by a large number of compounds and most of them in a low concentration below $0.1(\mathrm{v} / \mathrm{v})$. Over hundreds of organic compounds was found in the pyrolysis oil but only $0.1(\mathrm{v} / \mathrm{v})$ and above were listed in Table 3. Hydrocarbons, diolefin, aromatic and carboxylic acid groups are the major compound in the pyrolysis oil from the co-pyrolysis process. 2,4-dimethyl-1-heptene was found to be the highest with $8.05(\mathrm{v} / \mathrm{v})$ in pyrolysis oil. Alkenes such as hexane, pentene and octane can also be detected in the oil. This result is an agreement with result obtained by Sophonrat et al, 2017, when cellulose is co-pyrolyzed with PP plastic [24]. Comparing with 
pyrolysis of RWS only [6], mixing PP to RWS increased longer chain hydrocarbons in the pyrolysis oil. Similar result is obtained by Ballice et al 2002 when co-pyrolysis experiment is done with lignite and PP [25].

Table 3. Organic compounds in pyrolysis oil from co-pyrolysis of RWS with PP.

\begin{tabular}{|c|c|c|c|}
\hline Compound & $\%$ Area & Compound & $\%$ Area \\
\hline Alkanes & & Diolefins & \\
\hline Cyclobutane $\left(\mathrm{C}_{4} \mathrm{H}_{8}\right)$ & 0.55 & 2,4-Hexadiene $\left(\mathrm{C}_{6} \mathrm{H}_{10}\right)$ & 0.22 \\
\hline Cyclopropane $\left(\mathrm{C}_{3} \mathrm{H}_{6}\right)$ & 0.58 & 1,3-Pentadiene $\left(\mathrm{C}_{5} \mathrm{H}_{8}\right)$ & 0.91 \\
\hline Eicosene $\left(\left[\mathrm{CH}_{2}\right]_{18}-\mathrm{CH}_{3}\right)$ & 0.23 & 1,5-Hexadiene $\left(\mathrm{C}_{6} \mathrm{H}_{10}\right)$ & 0.71 \\
\hline Cyclo-octacosane $\left(\mathrm{C}_{28} \mathrm{H}_{56}\right)$ & 0.21 & 1,4-cyclohexadiene $\left(\mathrm{C}_{6} \mathrm{H}_{8}\right)$ & 0.24 \\
\hline Cyclohexane $\left(\mathrm{C}_{6} \mathrm{H}_{12}\right)$ & 1.23 & 1,4-Hexadiene $\left(\mathrm{C}_{6} \mathrm{H}_{10}\right)$ & 0.42 \\
\hline 2,3-Dimethyl-3-heptane $\left(\mathrm{C}_{8} \mathrm{H}_{16}\right)$ & 1.65 & 1,5-Heptadiene $\left(\mathrm{C}_{7} \mathrm{H}_{12}\right)$ & 0.37 \\
\hline Octane $\left(\mathrm{C}_{8} \mathrm{H}_{18}\right)$ & 0.41 & 2-Methyl-1,5-Heptadiene $\left(\mathrm{C}_{7} \mathrm{H}_{12}\right)$ & 0.20 \\
\hline Heptane $\left(\mathrm{C}_{7} \mathrm{H}_{16}\right)$ & 1.07 & 1,3-Hexadiene $\left(\mathrm{C}_{6} \mathrm{H}_{10}\right)$ & 0.15 \\
\hline Alkenes & & 1,4-Hexadiene $\left(\mathrm{C}_{6} \mathrm{H}_{10}\right)$ & 0.58 \\
\hline 2-Heptene $\left(\mathrm{C}_{7} \mathrm{H}_{14}\right)$ & 0.28 & 1,7-Nonadiene $\left(\mathrm{C}_{9} \mathrm{H}_{16}\right)$ & 0.17 \\
\hline 1,3,5-Hexatriene $\left(\mathrm{C}_{6} \mathrm{H}_{8}\right)$ & 0.95 & 1,12-Tridecadiene $\left(\mathrm{C}_{13} \mathrm{H}_{24}\right)$ & 0.19 \\
\hline 2,4-Dimethyl-1-heptene $\left(\mathrm{C}_{9} \mathrm{H}_{18}\right)$ & 8.05 & Esters & \\
\hline $\begin{array}{l}\text { 1,3-Dimethylcyclohexene } \\
\left(\mathrm{C}_{8} \mathrm{H}_{14}\right)\end{array}$ & 0.20 & $\begin{array}{l}\text { Octacosyl Trifluoroacetate } \\
\left(\mathrm{C}_{30} \mathrm{H}_{57} \mathrm{~F}_{3} \mathrm{O} 2\right)\end{array}$ & 0.82 \\
\hline Heptene $\left(\mathrm{C}_{7} \mathrm{H}_{14}\right)$ & 0.12 & Carboxylic Acids & \\
\hline 2-Octene $\left(\mathrm{C}_{8} \mathrm{H}_{16}\right)$ & 1.30 & Oxalic acid $\left(\mathrm{C}_{2} \mathrm{H}_{2} \mathrm{O}_{4}\right)$ & 0.22 \\
\hline 2-Undecene $\left(\mathrm{C}_{11} \mathrm{H}_{22}\right)$ & 0.27 & Fumaric acid $\left(\mathrm{C}_{4} \mathrm{H}_{4} \mathrm{O}_{4}\right)$ & 0.16 \\
\hline Cyclodecene $\left(\mathrm{C}_{10} \mathrm{H}_{20}\right)$ & 0.15 & Cyclopropanecarboxylic acid $\left(\mathrm{C}_{4} \mathrm{H}_{6} \mathrm{O}_{2}\right)$ & 0.32 \\
\hline Dodecene $\left(\mathrm{C}_{10} \mathrm{H}_{21} \mathrm{CH}=2\right)$ & 0.17 & 2-Butenoic Acid & 0.94 \\
\hline Cyclododecane $\left(\left(\mathrm{CH}_{2}\right)_{12}\right)$ & 0.18 & Acetic acid $\left(\mathrm{CH}_{3} \mathrm{COOH}\right)$ & 0.22 \\
\hline 1-Heptadecene $\left(\mathrm{C}_{17} \mathrm{H}_{34}\right)$ & 0.20 & Aromatics & \\
\hline 3-Octadecene $\left(\mathrm{C}_{18} \mathrm{H}_{36}\right)$ & 0.24 & Ethylbenzene $\left(\mathrm{C}_{6} \mathrm{H}_{5} \mathrm{CH}_{2} \mathrm{CH}_{3}\right)$ & 0.83 \\
\hline Pentene $\left(\mathrm{C}_{5} \mathrm{H}_{10}\right)$ & 1.13 & 2-Methylindene $\left(\mathrm{C}_{10} \mathrm{H}_{10}\right)$ & 0.28 \\
\hline Cyclohexene $\left(\mathrm{C}_{6} \mathrm{H}_{10}\right)$ & 1.37 & Benzene $\left(\mathrm{C}_{6} \mathrm{H}_{6}\right)$ & 4.12 \\
\hline Toluene $\left(\mathrm{C}_{7} \mathrm{H}_{8}\right)$ & 4.29 & Phenols & \\
\hline Hexene $\left(\mathrm{C}_{6} \mathrm{H}_{12}\right)$ & 1.55 & Phenol $\left(\mathrm{C}_{6} \mathrm{H}_{5} \mathrm{OH}\right)$ & 0.21 \\
\hline 2-pentene $\left(\mathrm{C}_{5} \mathrm{H}_{10}\right)$ & 1.91 & Phenyls & \\
\hline 2-octene $\left(\mathrm{C}_{8} \mathrm{H}_{16}\right)$ & 1.30 & 3-Aminopyrazole $\left(\mathrm{C}_{3} \mathrm{H}_{5} \mathrm{~N}_{3}\right)$ & 0.87 \\
\hline Benzyl Alcohols & & Hydroxyls & \\
\hline $\begin{array}{l}\text { Benzenemethanol } \\
\left(\mathrm{C}_{6} \mathrm{H}_{5} \mathrm{CH}_{2} \mathrm{OH}\right)\end{array}$ & 0.26 & Cyclohexanol $\left.\left(\mathrm{HOCH}\left(\mathrm{CH}_{2}\right)_{5}\right)\right)$ & 0.30 \\
\hline Ketones & & Cyclopropylmethanol $\left(\mathrm{C}_{4} \mathrm{H}_{8} \mathrm{O}\right)$ & 0.70 \\
\hline Cyclopentanone $\left(\left(\mathrm{CH}_{2}\right)_{4} \mathrm{CO}\right)$ & 0.30 & Polycylic Aromatics & \\
\hline Ethanone $\left(\mathrm{C}_{10} \mathrm{H}_{16} \mathrm{O}\right)$ & 0.70 & Naphthalene $\left(\mathrm{C}_{10} \mathrm{H}_{8}\right)$ & 0.19 \\
\hline Benzoate & & Silane & \\
\hline Benzoic acid $\left(\mathrm{C}_{7} \mathrm{H}_{6} \mathrm{O}_{2}\right)$ & 0.48 & Triallylsilane $\left(\mathrm{C}_{9} \mathrm{H}_{15} \mathrm{Si}\right)$ & 0.62 \\
\hline \multicolumn{4}{|l|}{ Acyclic olefin } \\
\hline 4-methyl-2-heptene $\left(\mathrm{C}_{8} \mathrm{H}_{6}\right)$ & 1.90 & & \\
\hline
\end{tabular}


Non-condensable gases (NCG) were collected in the gas bag and the composition analysis is often disregarded by many researchers. NCG has brownish vapour colour and has an acrid odor. Figure 7 shows the gas composition analysis of NCG. In this study, carbon monoxide (52.2 vol.\%) and carbon dioxide (38.2 vol.\%) were the major gas components.

घnknown gas $\square$ Carbon dioxide $\square$ Carbon monoxide $\square$ Methane $\square$ Hydrogen

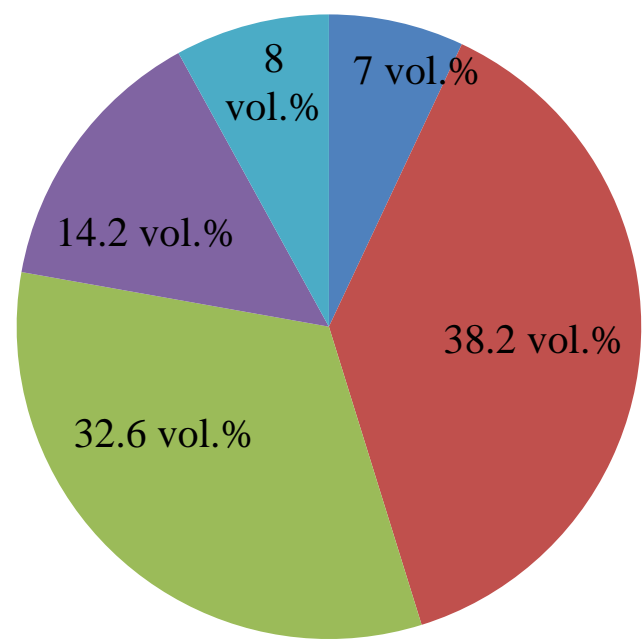

Figure 7. Non-condensable gas (NCG) composition

\section{CONCLUSION}

In this work, the effect of co-pyrolysis of RWS with PP at different temperatures with 1:1 ratio was investigated. The products yields of pyrolysis oil, biochar, non-condensable gases and their composition were discussed. The yield of pyrolysis oil has an inclined trend as the temperature increased from $450^{\circ} \mathrm{C}$ to $550^{\circ} \mathrm{C}$ because of the continuous pyrolysis conversion at the higher temperature. However, the pyrolysis oil abruptly dropped at temperature $600^{\circ} \mathrm{C}$, assuming and producing more gases. Co-pyrolysis of RWS and PP generated maximum pyrolysis oil with $36.47 \mathrm{wt} . \%$ at $500^{\circ} \mathrm{C}$. However, the comparison between pyrolysis of RWS alone was done with the same weight to compare the product yields with co-pyrolysis product yields and maximum pyrolysis oil yield obtained was $33.3 \mathrm{wt} . \%$. The water content in pyrolysis oil of co-pyrolysis RWS with PP is lower than RWS only with 54.2 wt.\% and 62 wt.\% respectively. Hydrocarbons, acyclic olefin, alkyl and aromatic groups are the major compound in the pyrolysis oil from the co-pyrolysis process. Carbon monoxide (52.2 vol.\%) and carbon dioxide (38.2 vol.\%) were the major gas components.

It can be concluded that mixing RWS with PP as the feedstock has many advantages. Apart from higher pyrolysis oil yield, the quality of the oil was also improved with higher calorific value and lower water content. For future research, investigation of co-pyrolysis of RWS and PP in a larger scale continuous fluidized-bed pyrolyzer is important to fully understand this process in a larger scale. 


\section{ACKNOWLEDGMENTS}

The authors would like to thank the Ministry of Education of Malaysia for the financial support under the Research Acculturation Grant Scheme (RAGS), grant number of RAGS/1/2015/TK03/UNIMAP/03/2 and the Centre for Biofuel and Biochemical Research, Universiti Teknologi PETRONAS for providing the facilities and technical support for this work.

\section{REFERENCES}

[1] Lehmann J. Bio-energy in the black. Frontiers in Ecology and the Environment 2007; 5(7) : 381-387

[2] Tomei J \& R Helliwell, Food versus fuel? Going beyond biofuels. Land Use Policy 2016; 56: 320-326

[3] Ratnasingam J, G Ramasamy, LT Wai, AL Senin, \& N Muttiah, The prospects of rubberwood biomass energy production in Malaysia. BioResources 2015; 10(2): 2526-2548

[4] Awalludin MF, O Sulaiman, R Hashim, \& WNAW Nadhari, An overview of the oil palm industry in Malaysia and its waste utilization through thermochemical conversion, specifically via liquefaction. Renewable and Sustainable Energy Reviews 2015; 50: 1469-1484

[5] Khin AA, J Jacob, KLL Teng, RLL Bin, \& WH Chau, Forecasting Technology Using for Dynamic Natural Rubber Production Models in Selected Asean Countries and World Market. Advanced Science Letters 2018; 24(5): 3368-3373

[6] Mazlan MAF, Y Uemura, NB Osman, \& S Yusup, Fast pyrolysis of hardwood residues using a fixed bed drop-type pyrolyzer. Energy Conversion and Management 2015; 98: 208-214

[7] Ahmad R, N Hamidin, UFM Ali, \& CZA Abidin, Characterization of Bio-Oil From Palm Kernel Shell Pyrolysis. Journal of Mechanical Engineering and Sciences 2015; 7: $1134-1140$

[8] Huber GW, S Iborra, \& A Corma, Synthesis of transportation fuels from biomass: Chemistry, catalysts, and engineering. Chemical Reviews. 2006; 106(9) : 4044-4098

[9] Demirbas A, Progress and recent trends in biodiesel fuels. Energy Conversion and Management 2009; 50(1): 14-34

[10] Önal E, BB Uzun, \& AE Pütün, Bio-oil production via co-pyrolysis of almond shell as biomass and high density polyethylene. Energy Conversion and Management 2014; 78: 704-710

[11] Paradela F, F Pinto, I Gulyurtlu, I Cabrita, \& N Lapa, Study of the co-pyrolysis of biomass and plastic wastes. Clean Technologies and Environmental Policy 2009; 11(1): $115-122$

[12] Shadangi KP \& K Mohanty, Co-pyrolysis of Karanja and Niger seeds with waste polystyrene to produce liquid fuel. Fuel 2015; 153: 492-498

[13] Baskaran R \& SK P, Evaluation on performance of CI engine with Waste Plastic oilDiesel blends as Alternative fuel 2015; 3(Iv): 642-646

[14] Geyer R, JR Jambeck, \& KL Law, Production, use, and fate of all plastics ever made. Science advances 2017; 3(7): e1700782 
[15] Mazlan MAF, Y Uemura, N Osman, \& S Yusup, Review on Pyrolysis of Hardwood Residue to Biofuel. Applied Mechanics and Materials. 2014; 625: 714-717

[16] Phyllis2, rubberwood (\#2519), Database for biomass and waste, 2003. [Online]. Available: https://www.ecn.nl/phyllis2/Biomass/View/2519. [Accessed: 16-Jul2018]

[17] Ly HV, SS Kim, JH Choi, HC Woo, \& J Kim, Fast pyrolysis of Saccharina japonica alga in a fixed-bed reactor for bio-oil production. Energy Conversion and Management 2016; 122: 526-534

[18] Brebu M, S Ucar, C Vasile, \& J Yanik, Co-pyrolysis of pine cone with synthetic polymers. Fuel 2010; 89(8): 1911-1918

[19] Westerhof RJM, NJM Kuipers, SRA Kersten, \& WPM Van Swaaij, Controlling the water content of biomass fast pyrolysis oil, in Industrial and Engineering Chemistry Research 2007, . 2007; 46(26), : 9238-9247

[20] Abnisa F \& WMA Wan Daud, A review on co-pyrolysis of biomass: An optional technique to obtain a high-grade pyrolysis oil. Energy Conversion and Management 2014; 87: 71-85

[21] Ali I \& MA Basit, Significance of hydrogen content in fuel combustion. International Journal of Hydrogen Energy 1993; 18(12): 1009-1011

[22] Dong C, Z Zhang, Q Lu, \& Y Yang, Characteristics and mechanism study of analytical fast pyrolysis of poplar wood. Energy Conversion and Management 2012; 57: 49-59

[23] Mullen CA, AA Boateng, NM Goldberg, IM Lima, DA Laird, \& KB Hicks, Bio-oil and bio-char production from corn cobs and stover by fast pyrolysis. Biomass and Bioenergy 2010; 34(1): 67-74

[24] Sophonrat N, L Sandström, A-C Johansson, \& W Yang, Co-pyrolysis of mixed plastics and cellulose: an interaction study by Py-GCX GC/MS. Energy \& Fuels. 2017; 31(10): 11078-11090

[25] Ballice L \& R Reimert, Temperature-programmed co-pyrolysis of Turkish lignite with polypropylene. Journal of Analytical and Applied Pyrolysis 2002; 65(2): 207219 